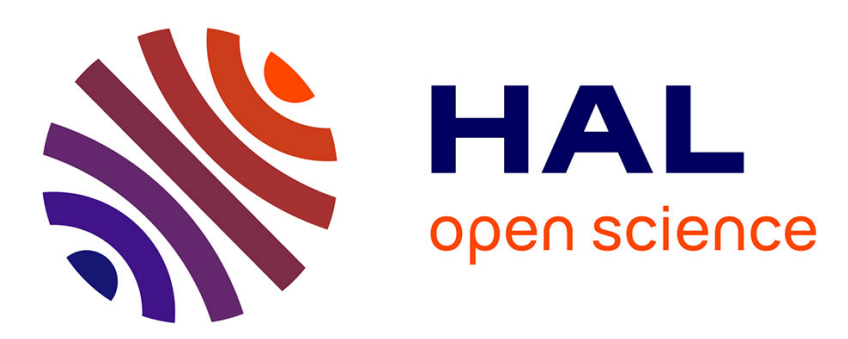

\title{
Intake and digestibility of different forages in Hamas compared to sheep
}

Jean-Pierre Dulphy, Claude Dardillat, Marie Jailler, Jean-Pierre Jouany

\section{To cite this version:}

Jean-Pierre Dulphy, Claude Dardillat, Marie Jailler, Jean-Pierre Jouany. Intake and digestibility of different forages in Hamas compared to sheep. Annales de zootechnie, 1998, 47 (1), pp.75-81. hal00889715

\section{HAL Id: hal-00889715 https://hal.science/hal-00889715}

Submitted on 1 Jan 1998

HAL is a multi-disciplinary open access archive for the deposit and dissemination of scientific research documents, whether they are published or not. The documents may come from teaching and research institutions in France or abroad, or from public or private research centers.
L'archive ouverte pluridisciplinaire HAL, est destinée au dépôt et à la diffusion de documents scientifiques de niveau recherche, publiés ou non, émanant des établissements d'enseignement et de recherche français ou étrangers, des laboratoires publics ou privés. 


\title{
Intake and digestibility of different forages in llamas compared to sheep
}

\author{
Jean-Pierre Dulphy*, Claude Dardillat, \\ Marie Jailler, Jean-Pierre Jouany
}

\begin{abstract}
Station de recherches sur la nutrition des herbivores, Inra, Theix, 63122 Saint-Genès-Champanelle, France
\end{abstract}

(Received 12 February 1997; accepted 5 September 1997)

\begin{abstract}
Results of four trials, in which intake and digestibility of nine roughages had been measured, were pooled to make a comparison between llamas and sheep fed dry forages. Llamas and sheep ingest, on average, similar levels of dry matter: 15.8 against $17.7 \mathrm{~g} \mathrm{DM} / \mathrm{kg} \mathrm{LW}$, or 49.2 against $51.1 \mathrm{~g} \mathrm{DM} / \mathrm{kg} \mathrm{LW}^{0.75}$. The values for each species are significantly related, but with a low slope, llamas ingest more straw and a lower quantity of high-graded forages than sheep. Overall mean digestibility in llamas is better than in sheep: +2.5 points for $\mathrm{OM}$ and +4.3 for cell walls. Digestibilities in both species are well correlated, with an important difference for the lowgraded, but no difference for high-graded forages. The mean level of non-digestible crude protein content of diets is higher by $4 \mathrm{~g} / \mathrm{kg}$ DM in llamas than in sheep. For each species the intake and digestibilities are positively related to the crude protein content of the roughages and negatively to their NDF content. (C) Elsevier / Inra.)
\end{abstract}

\section{intake / digestibility / roughage / llama / sheep}

Résumé - Comparaison de l'ingestibilité et de la digestibilité de différents fourrages chez le lama et le mouton. Les résultats de quatre essais, dans lesquels les quantités ingérées et les digestibilités de neuf fourrages ont été mesurées, ont été regroupés pour mieux comparer les lamas et les moutons recevant ces fourrages. En moyenne, lamas et moutons ont ingéré des quantités de matière sèche proches : 15,8 contre $17,7 \mathrm{en} \mathrm{g} / \mathrm{kg}$ de $\mathrm{PV}$, et 49,2 contre $51,1 \mathrm{en} \mathrm{g/kg} \mathrm{de} \mathrm{PV}{ }^{0.75}$. Ces quantités sont étroitement liées entre les deux espèces, mais avec une pente de 0,5 , les lamas ingèrent plus de fourrages pauvres et moins de bons fourrages que les moutons. En revanche, les lamas ont mieux digéré les fourrages que les moutons : $+2,5$ points pour la MO et $+4,3$ pour les parois (NDF). Les digestibilités sont bien reliées entre les deux espèces, avec un écart important pour les fourrages riches en parois et pas d'écart pour les fourrages pauvres en parois. La teneur en matières azotées non digestibles des fourrages est plus élevée de $4 \mathrm{~g}$ chez les lamas que chez les moutons. Pour chaque espèce l'ingestibilité et les digestibilités sont positivement

\footnotetext{
* Correspondence and reprints
} 
reliées à la teneur en MAT et négativement à celle en parois végétales des fourrages. (C) Elsevier / Inra.)

quantité ingérée / digestibilité / fourrage / lamas / moutons

\section{INTRODUCTION}

Most of the feeding trials carried out on llamas and sheep, as reviewed by Dulphy et al. [6], show that llamas ingest less high-quality forage and more low-quality forage per $\mathrm{kg}$ liveweight than sheep. Also, forage digestibility is reported to be higher in llamas than in sheep.

Because these first results come from different laboratories, and in order to have a more coherent approach, results obtained in four trials carried out in our laboratory were pooled to evaluate relationships between forage quality and intake and digestion capacities in llamas and sheep. Nine different forages fed during these trials were chosen so that their characteristics would cover the full range of forage qualities that could be fed to these species.

This assessment is especially justified as some other results $[10,13]$ for the digestibility of several forages are in disagreement (sheep showing higher digestibilities) with those reviewed previously [6].

\section{MATERIALS AND METHODS}

Altogether, results of four trials were used: trial 1, Dulphy et al. [3] (natural meadow hay 1, straw 1); trial 2, Lemosquet et al. [9] (natural meadow hay 2, cocksfoot hay); trial 3, Dulphy et al. [2] (natural meadow hay 3 and 4, tall fescue hay 1, straw 2); trial 4, Dulphy et al. [4] (tall fescue hay 2).

In each case experimental conditions of trials are given in the corresponding paper. Each year three to six animals of each species were used. A total of eight different llamas were used in these four trials. Forages were all fed ad libitum, as unsupplemented for the seven hays and with a nitrogen-rich complement for the two straws. Refusals were limited between 10 and $20 \%$, enabling animals to eat voluntarily while reducing the possibilities of selection.

Special individual pens were built for the llamas based on individual metabolism pens designed for sheep. All digestibilities were calculated following total fecal collection during 6 days.

Each forage was characterized by its total nitrogen content (Kjeldahl method) expressed as crude protein (CP) and total plant cell wall content (NDF measured according the method of Goering and Van Soest [7]) (table I). Parameters measured were: voluntary intake of dry matter (DM) (per kg liveweight (LW) and per $\mathrm{kg} \mathrm{W}^{0.75}$ ), digestibility (OM and NDF) and content of non-digestible total nitrogen (expressed as g non-digestible CP/kg ingested DM, NDCP). This last parameter was included because apparent digestibility of total nitrogen depends closely on total nitrogen content of feed offered. Digestibilities of concentrates were assigned digestibilities taken from tables [8], who allowed to calculate individual digestibilities of the straws.

Comparisons between species were made on the pooled values by analysis of variance. We then calculated the correlations between llamas and sheep, and lastly those linking parameters in each species to forage composition.

\section{RESULTS}

\subsection{Voluntary DM intake}

Mean values of voluntary DM intake for the nine forages are given in table II. There are no significant differences in DM intake between llamas and sheep, despite the lower values for llamas; respectively -11 and $-4 \%$ when expressed in $\mathrm{g} / \mathrm{kg}$ liveweight or metabolic weight.

However, if the two straws are not taken into account, difference between 
Table I. Chemical composition of studied forages ( $\mathrm{g} / \mathrm{kg} \mathrm{DM}$ ).

\begin{tabular}{lcc}
\hline & Crude protein & Cell wall content (NDF) \\
\hline Trial 1 & 94 & 706 \\
- Hay (natural grassland 1) & 58 & 769 \\
- Straw 1 & & \\
Trial 2 & 79 & 669 \\
- Hay (natural grassland 2) & 118 & 710 \\
- Hay (cockfoot) & & \\
Trial 3 & 147 & 628 \\
- Hay (natural grassland 3) & 110 & 648 \\
- Hay (natural grassland 4) & 51 & 711 \\
- Hay (tall fescue 1) & 37 & 832 \\
- Straw 2 & & \\
Trial 4 & 68 & 667 \\
- Hay (tall fescue 2) & & \\
\hline
\end{tabular}

Table II. Compared feeding values of the nine forages fed to llamas and sheep (concentrate fed with straws excluded).

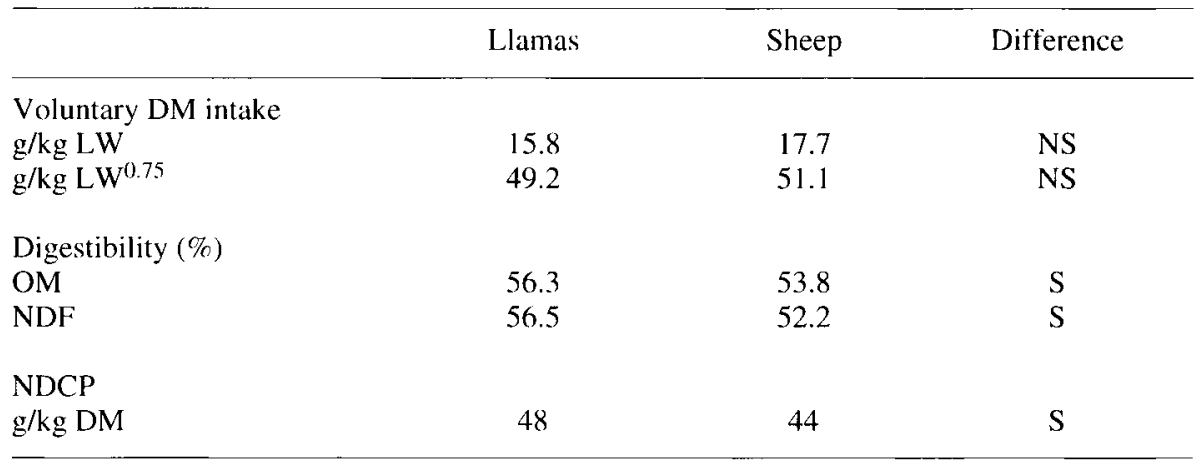

OM, organic mater; NDF, neutral detergent fiber; NDCP, non digestible crude protein; NS, not significant $(P>0.05) ;$ S, significant $(P \leq 0.05)$.

species become significant when expressed in $\mathrm{g} / \mathrm{kg} \mathrm{W}$ ( 16.9 for llamas versus 19.8 for sheep; $-15 \%, P=0.05)$, but not in $\mathrm{g} / \mathrm{kg} \mathrm{W}^{0.75}(52.9$ versus $57.5 ;-8 \%)$.

In addition, intake levels of llamas and sheep are closely related. The moderate slope of the regression, approximately 0.5 , is significantly less than 1 . This indicates that llamas are less sensitive to the quality of forage than sheep (figures 1 and 2). This is confirmed by a significant interaction between species and composition of forages (table III).

The intake of llamas is significantly positively correlated with total nitrogen content and negatively with NDF content. In contrast, intake of sheep is only significantly correlated with NDF content 
Table III. Relationships between, CP and NDF content and feeding values of forages in llamas and sheep. $(\mathrm{y}=\mathrm{ax}+\mathrm{b} ; \mathrm{L}=$ llamas: $\mathrm{S}=$ sheep $)(n=9)$.

\begin{tabular}{|c|c|c|c|c|c|c|}
\hline & & Slope a & b & $\mathrm{SD}( \pm)$ & $\mathrm{R}^{*}$ & $\begin{array}{c}\text { Interaction } \\
\text { species } x \\
\text { chemical composition }\end{array}$ \\
\hline \multicolumn{7}{|l|}{$C P(g / k g D M)$} \\
\hline \multicolumn{7}{|c|}{ - Voluntary DM Intake } \\
\hline \multirow{2}{*}{ - $\mathrm{g} / \mathrm{kg} \mathrm{LW}$} & $\mathbf{L}$ & 0.0703 & 9.82 & 1.66 & 0.85 & ) \\
\hline & $\mathrm{S}$ & 0.0753 & 11.29 & 4.43 & 0.54 & $\mathrm{~S}$ \\
\hline \multirow[t]{2}{*}{$\cdot \mathrm{g} / \mathrm{kgLW}^{0.75}$} & $\mathrm{~L}$ & 0.200 & 32.3 & 5.8 & 0.80 & ) \\
\hline & $\mathrm{S}$ & 0.234 & 31.3 & 12.7 & 0.57 & ) $S$ \\
\hline \multicolumn{7}{|c|}{ - Digestibility (\%) } \\
\hline \multirow[t]{2}{*}{ OM } & L & 0.165 & 42.4 & 3.7 & 0.86 & ) \\
\hline & $\mathrm{S}$ & 0.166 & 39.7 & 4.8 & 0.80 & ) $S$ \\
\hline \multirow[t]{2}{*}{ NDF } & $\mathbf{L}$ & 0.166 & 42.4 & 2.9 & 0.91 & ) \\
\hline & $\bar{S}$ & 0.179 & 37.0 & 4.3 & 0.84 & $S$ \\
\hline \multicolumn{7}{|l|}{ - NDCP/kgDM) } \\
\hline & $\mathbf{L}$ & 0.100 & 39.3 & 5.3 & 0.58 & ) \\
\hline & $\mathrm{S}$ & 0.109 & 34.8 & 5.3 & 0.61 & ) $S$ \\
\hline \multicolumn{7}{|l|}{$N D F(g / k g D M)$} \\
\hline \multicolumn{7}{|c|}{ - Voluntary DM intake } \\
\hline \multirow[t]{2}{*}{$\bullet \mathrm{g} / \mathrm{kg} \mathrm{LW}$} & $\mathbf{L}$ & -0.0398 & 43.85 & 1.62 & 0.86 & 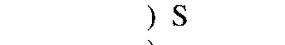 \\
\hline & $\mathrm{S}$ & -0.0629 & 62.03 & 3.10 & 0.81 & ) \\
\hline \multirow[t]{2}{*}{ - $\mathrm{g} / \mathrm{kgLW}^{0.75}$} & L & -0.124 & 136.6 & 4.5 & 0.88 & $S$ \\
\hline & $\mathrm{S}$ & -0.195 & 188.6 & 8.2 & 0.85 & ) \\
\hline \multicolumn{7}{|c|}{ - Digestibility (\%) } \\
\hline \multirow[t]{2}{*}{$\mathrm{OM}$} & $\mathrm{L}$ & -0.101 & 127.8 & 2.4 & 0.94 & ) $S$ \\
\hline & $\mathrm{S}$ & -0.100 & 124.0 & 4.2 & 0.85 & ) \\
\hline \multirow[t]{2}{*}{ NDF } & $\mathrm{L}$ & -0.071 & 107 & 5.0 & 0.70 & ) $S$ \\
\hline & $\mathrm{S}$ & -0.078 & 106.8 & 6.1 & 0.65 & ) \\
\hline \multicolumn{7}{|c|}{ - NDCP (g/kg DM) } \\
\hline & $\mathrm{L}$ & -0.011 & 55.4 & 6.5 & 0.11 & ) NS \\
\hline & $\mathrm{S}$ & -0.026 & 62 & 6.6 & 0.26 & ) \\
\hline \multicolumn{3}{|c|}{ * significant threshold: } & $\begin{array}{l}R=0.55 \\
R=0.63 \\
R=0.76\end{array}$ & & $\begin{array}{l}P=0.10 \\
P=0.05 \\
P=0.01\end{array}$ & \\
\hline
\end{tabular}

OM, organic matter; NDF, neutral detergent fiber; NDCP, non digestible crude protein; S, significant $(P<0.05)$; NS, non-significant $(P>0.05)$.

(table III). Correlations after multiple regression are slightly better: $\mathrm{R}=0.92$ and 0.91 in llamas, $R=0.81$ and 0.85 in sheep.

\subsection{Digestibility}

On average, digestibility of $\mathrm{OM}$ and NDF is significantly higher in llamas than in sheep (respectively, +2.5 and +4.3 points; table $I I$ ). These digestibilities in both species are significantly correlated (figures 3 and 4), with a slope less than 1 , more evidently for NDF. Under these conditions, differences between the two species are largest for the lowest digestibility roughages: respectively +4.2 and 


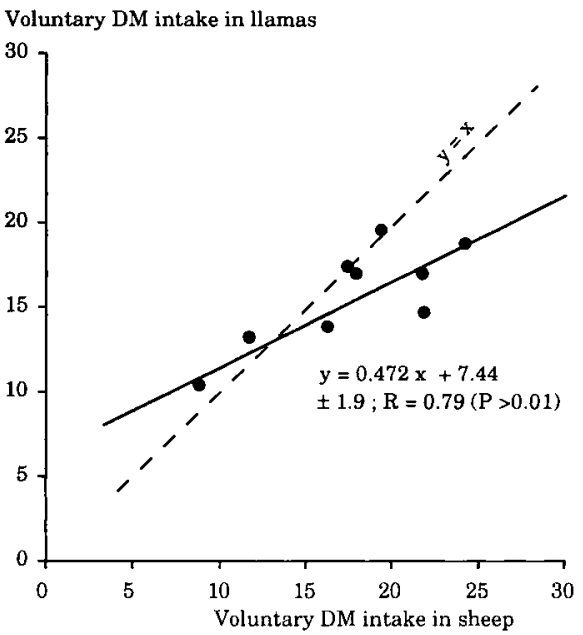

Figure 1. Relationship between voluntary DM intake in sheep and in llamas $(\mathrm{g} / \mathrm{kg} \mathrm{LW})$.

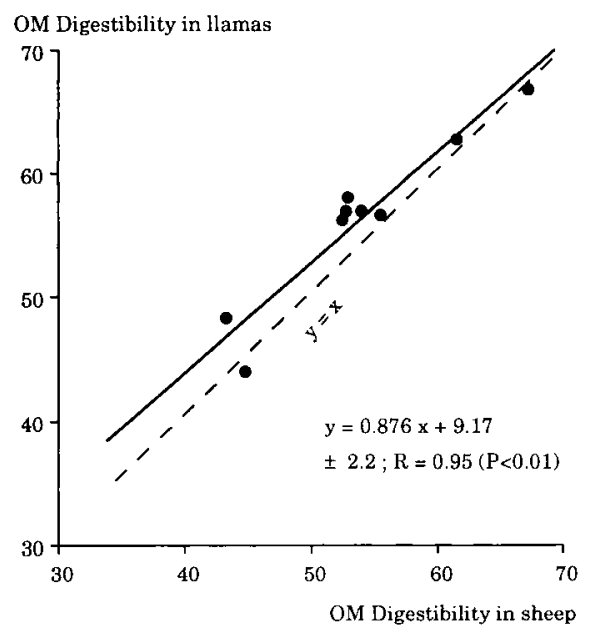

Figure 3. Relationship between $\mathrm{OM}$ digestibility in sheep and in Ilamas (\%).

+7.0 units for llamas, but almost nonexistent for the high-quality roughages. Indeed, there is also a significant interaction between species and composition of forages (table III).

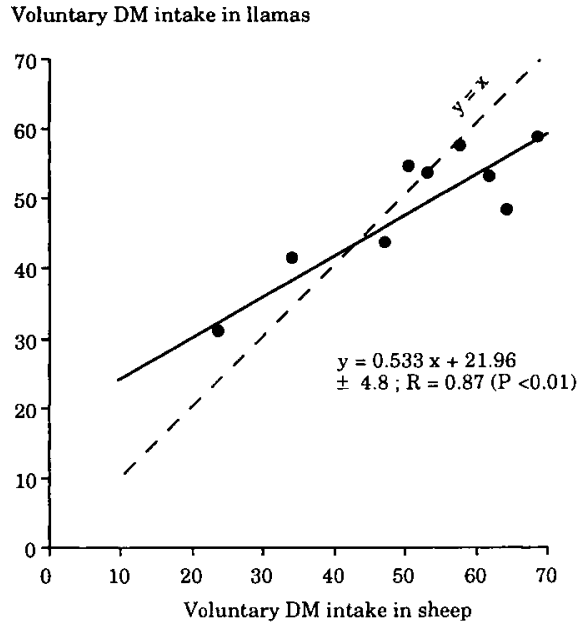

Figure 2. Relationship between voluntary DM intake in sheep and in llamas $\left(\mathrm{g} / \mathrm{kg} \mathrm{LW}{ }^{0.75}\right)$.

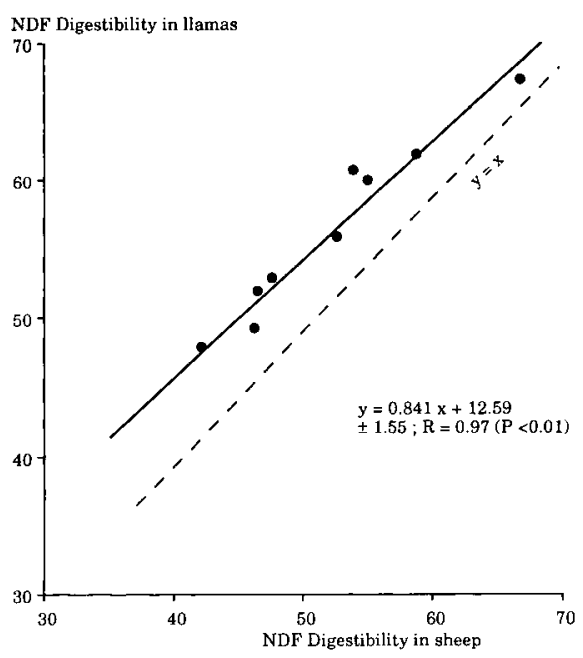

Figure 4. Relationship between NDF digestibility in sheep and in llamas (\%).

The variations in OM digestibility are best accounted for by variations in NDF, especially for llamas, but unexpectedly, NDF digestibility is better related to total CP content (table III). Correlations after 


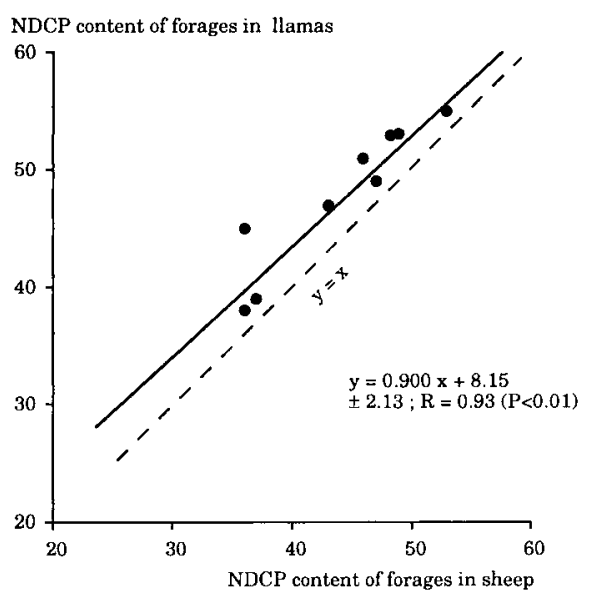

Figure 5. Relationship between non-digestible crude protein (NDCP) in sheep and in llamas ( $\mathrm{g} / \mathrm{kg}$ VDMI).

multiple regression are respectively $\mathrm{R}=0.98$ and 0.91 in llamas, $\mathrm{R}=0.89$ and 0.85 in sheep.

\subsection{Non-digestible crude protein content}

Non-digestible crude protein content was highest in llamas compared to sheep $(+4 \mathrm{~g} / \mathrm{kg}$ of offered dry matter; table $I I)$. The correlation between the values found for llamas and those for sheep is significant with a slope near to 1 (figure 5).

The non-digestible crude protein content depends only weakly on forage composition. It is best correlated with total crude protein content, but non-significantly (table III).

\section{DISCUSSION}

The average intake of dry matter in sheep $\left(51.1 \mathrm{~g} / \mathrm{kg} \mathrm{W}^{0.75}\right)$ is practically the same as that given by the equation of Dulphy et al. [5] for grass hays $(52 \mathrm{~g} / \mathrm{kg} \mathrm{W}$
0.75 ) for a NDF content of $704 \mathrm{~g} / \mathrm{kg}$ DM. The intake values for sheep may therefore be considered as representative. Intake values for llamas support the conclusion of Dulphy et al. [6] that llamas ingest poor forages better than sheep, but ingest highquality forages to a lesser extent. These results are also in agreement with those of Warmington et al. [12] who fed poor forage and Cordesse et al. [1] who fed two highly ingestible forages. Maintenancefed llamas probably adjust their feeding to their needs better than sheep. They probably are building up less fat than the 'standard' sheep used for comparison. Besides, their maintenance needs are lower than those of sheep [11].

Concerning extent of digestion, the superiority of llamas is confirmed here, especially for plant cell walls in poor forages. Results presented here are more consistent than those found in the literature compilation of Dulphy et al. [6] and confirm that the superiority of llamas decreases as digestibility increases. These findings are supported by those of Warmington et al. [12] and Cordesse et al. [1], who found little difference in digestibility between the two species. Some literature data are however in sharp disagreement with ours (e.g. some of those cited by San Martin and Bryant [10], and a study by Wauters et al. [13]). These results were obtained with apparently very free forage dispensing. Sheep may then have selected the forage more than llamas, choosing the more digestible parts of plants offered [10]. It may be also that some sheep are better adapted than others to digest poor forage, as suggested by Wauters et al. [13].

Llamas are therefore comparable to cattle in their ability to digest plant cell walls. The causes for differences in digestibility values between llamas and sheep have been discussed extensively elsewhere [4]; the llama has a slow transit, excellent intraruminal nitrogen recycling, efficient rumen $\mathrm{pH}$ regulating system. However, 
llamas excrete a little more nitrogen in their feces than sheep and, probably, more endogenous organic matter. Indeed, in the relationships between $\mathrm{CP}$ and NDCP differences between the two species concern essentially b (table III) which represents fecal non-alimentary CP. Elsewhere, the quantity of digestible NDF (NDF content $\times$ NDF digestibility) in offered forages is $32 \mathrm{~g}$ more in llamas, as compared to $23 \mathrm{~g}$ for digestible organic matter.

In conclusion, we confirm that characteristics of the feed value of forages (ingestibility, digestibility) are different in llamas and sheep. For poor forages, llamas are better adapted, and they ingest and digest plant cell walls better. For high quality forages there is no difference in digestibility, but llamas ingest less than sheep.

\section{REFERENCES}

[1] Cordesse R., Inesta M., Gaubert J.L., Intake and digestibility of four forages by llamas and sheep, Ann. Zootech. 41 (1992) 70 (abstract).

[2] Dulphy J.P., Ballet J.M., Jailler M., Detour A., Comparaison des activités alimentaires et méryciques de lamas et de moutons recevant des fourrages secs, Ann. Zootech. 46 (1997), 117-125.

[3] Dulphy J.P., Dardillat C., Jailler M., Jouany J.P., Comparison of the intake and digestibility of different diets in llamas and sheep: a preliminary study, Ann. Zootech. 43 (1994), 379-387.

[4] Dulphy J.P., Dardillat C., Jailler M., Ballet J.M., Comparative study of forestomach digestion in llamas and sheep, Reprod. Nutr. Dev. 37 (1997) 1-17.

[5] Dulphy J.P., Jailler M., Jamot J., Bousquet H., Amélioration de la prévision de la valeur alimentaire de certains foins au laboratoire, Fourrages, 121 (1990) 65-78.

[6] Dulphy J.P., Martin-Rosset W., Jouany J.P., Ingestion et digestion comparées des fourrages chez différentes espèces d'herbivores, Inra Prod. Anim. 8 (1995) 293-307.

[7] Goering H.K., Van Soest P.J., Forage fiber analysis, Agricultural Handbook, 379 (1970) $1-20$.

[8] Inra, Alimentation des bovins, ovins et caprins, Inra Editions, Paris, pp. 471, 1988.

[9] Lemosquet S., Dardillat C., Jailler M., Dulphy J.P., Voluntary intake and gastric digestion of two hays by llamas and sheep: influence of concentrate supplementation, J. Agric. Sci. Camb. 127 (1996) 539-548.

[10] San Martin F., Bryant F.C., Nutrition of domesticated south American llamas and Alpacas, Small Ruminant Res. 2 (1989) 191-216.

[11] Vernet J., Vermorel M., Jouany J.P., Digestibility and energy utilisation of three diets by llamas and sheep, Ann. Zootech. 46 (1997) 127-137.

[12] Warmington B.G., Wilson G.F., Barry T.N., Voluntary intake and digestion of ryegrass straw by llama $x$ guanaco crossbreds and sheep, J. Agric. Sci. Camb. 113 (1989) 87-91.

[13] Wauters J.J.M., Duchi N., Guerava P., Onate W., Castillo P., Lopez J., Dewilde R., Comparison of the digestibility of paja de paramo and barley straw between sheep, llamas and alpacas, J Camel Practice Res. 1 (1994) 106-108. 